\title{
Pengaruh Kompetensi, Independensi, dan Profesionalisme Auditor Internal Terhadap Kualitas Audit
}

\author{
Naomi Olivia Haryanto \\ Universitas Katolik Soegijapranata \\ Naomiolivia.no@gmail.com \\ Clara Susilawati \\ Universitas Katolik Soegijapranata
}

\begin{abstract}
The financial statements are used as consideration in decision making for the management of the company. Internal auditor's role is important for corporate sustainability. This is because internal audits are required as internal controls. Then the quality of the resulting audit depends on the competence, independence and also the auditor's own professionalism. The purpose of this study is to test empirically the influence of competence, independence and professionalisme internal auditors on audit quality in Semarang manufacturing company. Sampling method used is purposive sampling. The results showed that there is influence of competence, independence and professionalism on audit quality.
\end{abstract}

Keywords: Competence, Independence, Professionalism, Quality Audit.

\begin{abstract}
Abstrak
Laporan keuangan digunakan sebagai pertimbangan dalam pengambilan keputusan untuk pihak manajemen perusahaan. Peran internal auditor penting bagi keberlanjutan perusahaan. Hal tersebut dikarenakan audit internal diperlukan sebagai pengendalian internal.Maka kualitas audit yang dihasilkan bergantung dari kompetensi, independensi dan juga profesionalisme auditor itu sendiri. Tujuan penelitian ini adalah untuk menguji secara empiris pengaruh kompetensi, independensi dan profesioanlisme auditor internal terhadap kualitas audit di perusahaan manufaktur Semarang. Metoda penentuan sampel yang digunakan adalah purposive sampling. Hasil penelitian menunjukkan bahwa terdapat pengaruh kompetensi, independensi dan profesionalisme terhadap kualitas audit.
\end{abstract}

Kata kunci : Kompetensi, Independensi, Profesionalisme, Kualitas Audit.

\section{PENDAHULUAN}

Di dalam dunia bisnis, laporan keuangan merupakan suatu hal yang sangat penting. Hal ini dikarena laporan keuangan menjadi sebuah kunci bagi perusahaan untuk menilai mengenai keberlanjutan dari perusahaan itu sendiri dan juga digunakan sebagai pertimbangan dalam pengambilan sebuah keputusan untuk pihak manajemen perusahaan. Maka dari itu peran internal auditor sangatlah penting bagi keberlanjutan perusahaan. Menurut IIA dalam Sawyer (2012) menyatakan bahwa audit internal adalah kegiatan assurance dan konsultasi independen yang dirancang untuk menambah nilai dan meningkatkan operasi organisasi. Maka dari itu, audit internal sendiri diperlukan sebagai komponen integral dari tata kelola perusahaan berkelanjutan dan sebagai penyedia jaminan 
dan juga layanan dalam risiko manajemen, pelaporan keuangan, pengendalian internal serta proses tata kelola (Sihombing dan Indarto, 2014).

Tugas utama dari seorang auditor selain melaksanakan audit adalah memberikan opini yang sesuai dengan pedoman yaitu harus didasarkan pada sikap kompetensi,profesionalisme, tidak memihak atau independensi dan juga objektif(Mayasari, 2011). Hal itu berarti dalam melaksanakan audit para auditor harus memiliki kompetensi,independensi dan juga profesionalisme yang akan menentukan hasil ataupun kualitas audit. Kompetensi merupakan suatu keahlian, pengetahuan, pengalaman serta keterampilan yang diperlukan oleh seorang auditor dalam menjalankan tugas auditnya agar dapat melakukan audit secara cermat, objektif, dan juga seksama (Nugrahini, 2015). Sedangkan independensi adalah pertimbangan yang bersifat objektif, atau tidak memihak yang dimiliki oleh auditor dalam menyatakan pendapatnya berdasarkan pertimbangan fakta yang ada (Priyansari, 2015). Profesionalisme adalah kemampuan seseorang dalam menjalankan profesinya dengan baik (Andriandi, 2010).

Kualitas audit adalah karakteristik audit yang telah dapat memenuhi standar auditing dan juga standar pengendalian mutu yang telah menggambarkan praktik audit serta menjadi ukuran dari kualitas dalam pelaksanan tugas untuk memenuhi tanggung jawab profesinya (Nugrahini, 2015). Maka kompetensi, independensi dan juga profesionalisme sangat diperlukan oleh seorang auditor untuk menentukan kualitas audit (Agusti, 2013). Maka auditor harus tetap mempertahankan kompetensi, independensi dan profesionalisme yang dimiliki. Sehingga tetap dapat menghasilkan kualitas audit yang baik bagi perusahaan tersebut dan juga berguna bagi pemantauan dan keefektivan pengendalian internal dalam perusahaan tersebut.

Riset yang dilakukan Agusti dan Pertiwi (2013) mengenai kompetensi, independensi dan profesionalisme terhadap kualitas audit ini menghasilkan bahwa kompetensi, independensi dan profesionalisme berpengaruh pada kualitas audit. Penelitian-penelitian yang lain juga menemukan hasil yang konsisten (Alim et al., 2007; Ardini, 2010; Rumengan, 2014; Nteseo, 2013; Nugrahini, 2015. Namun beberapa penelitian lain menemukan hasil yang tidak konsisten (Andarwanto, 2015; Efendy, 2010).

Riset ini merupakan replikasi riset yang dilakukan oleh Agusti dan Pertiwi (2013). Tujuan riset ini untuk mengetahui apakah terdapat perbedaan hasil riset yang pernah dilakukan dahulu dengan riset yang akan dilakukan saat ini dengan sampel yang berbeda, dan untuk mengetahui apakah ada pengaruh positif dari kompetensi, independensi dan profesionalisme terhadap kualitas audit. Riset ini menggunakan sampel auditor internal di Semarang. Penelitian ini diharapkan dapat memberikan masukan bagi auditor dalam meningkatkan kualitas auditnya berdasarkan kompetensi, independensi dan juga profesionalisme yang dimilikinya.

\section{TINJAUAN LITERATUR DAN PERUMUSAN HIPOTESIS}

\section{Kompentensi}

Seorang auditor yang memiliki pengetahuan dan pengalaman yang cukup dan secara jelas dapat melaksanakan audit secara objektif, cermat dan juga sesksama disebut dengan kompetensi auditor (Agusti, 2013). Kompetensi merupakan hal yang dibutuhkan oleh auditor agar dapat melakukan audit dengan benar. Menurut kode etik IIA dalam Sawyer (2012) menyatakan bahwa kompetensi seorang auditor internal haruslah :

1. Hanya terlibat dalam layanan-layanan yang memerlukan pengetahuan, keterampilan, dan pengalaman yang mereka. 
2. Melakukan layanan audit internal sesuai dengan International Standards for the Professional Practice of Internal Auditing

3. Meningkatkan kemampuan mereka dan efektivitas dan kualitaslayanan mereka.

SAS no 65 dalam Sihombing dan Indarto(2014) menyatakan bahwa kompetensi audit internal dapat dinilai berdasarkan :

1. Tingkat pendidikan dan pengalaman professionalKompetensi auditor untuk menghasilkan kualitas hasil pemeriksaan dapat terbentuk oleh latar belakang pendidikan, dan juga pendidikan dan pelatihan yang memadai.

2. Sertifikasi profesi dan pendidikan profesi yang berkelanjutanAuditor haruslah memiliki sertifikat Jabatan Fungsional auditor (JFA), auditor juga harus mengikuti pendidikan dan pelatihan berkelanjutan dan auditor wajib memiliki pengetahuan dan akses atas informasi teraktual dalam standar, prosedur, metodologi serta teknik pemeriksaan.

3. Kebijakan, program, dan proses audit yang sedang digunakanStandar Profesi Internal Audit memiliki tujuan untuk memberikan kerangka dasar yang konsisten dalam mengevaluasi kegiatan, kebijakan, program dan juga kinerja unit internal audit.

4. Praktik yang berhubungan dengan penugasan stafPelaksanaan penugasan haruslah meliputi perencanaan, pelaksanaan pekerjaan lapangan dan pengevaluasian informasi serta pengkomunikasian hasil.

5. Supervisi dan penelaahan aktivitas auditKetua tim mengkoordinasi dan juga mereview terkait pelaksanaan penugasaan di lapangan, guna mendapatkan kepastian proses penugasaan telah dilaksanakan sesuai dengan perencanaan serta tujuan penugasan.

6. Kualitas dari dokumentasi kertas kerja, laporan dan rekomendasiInternal Auditor haruslah memantau dan juga melaporkannya kepada Direktur Utama ataupun Direktur terkait mengenai tindak lanjut yang dilaksanakan oleh pihak yang menjadi obyek dari penugasan

7. Evaluasi kinerja audit secara umumInternal Auditor haruslah memantau pelaksanaan instruksi Direktur utama terkait dengan menindaklanjuti saran-saran perbaikan kepada obyek penugasan.

\section{Independensi}

Menurut (Arens dkk.,2011 dalam Rumengan, 2014) menyatakan Independensi dalam ruang lingkup audit adalah cara pandang yang tidak memihak pada siapapun dalam melaksanakan pengujian,evaluasi hasil pemeriksaan dan juga penyusunan laporan audit. Bagi seorang auditor independensi merupakan hal yang sangat penting untuk menghasilkan jasa audit yang berkualitas. (Amilin dan Utami, 2008 dalam Suharti, 2013) menyatakan bahwa dalam melaksanakan sikap independennya seorang auditor tidak hanya melaksanakannya dalam pekerjaan lapangan semata melainkan juga dalam mengatur perencanaan atas aktivitas yang akan dilakukan dalam proses audit tersebut. Sawyer's (2012) menyatakan bahwa aktivitas audit internal akan tetap bebas dari campur tangan setiap elemen dalam organisasi, termasuk hal-hal seleksi audit, ruang lingkup, prosedur, frekuensi, waktu, atau isi laporan untuk mengizinkan pemeliharaan sikap mental yang diperlukan independen dan obyektif. Dalam standar umum yang telah ditetapkan oleh (IIA dalam Sihombing dan Indarto, 2014) dinyatakan bahwa independensi seorang auditor internal dapat dicapai apabila:

1. Kepala departemen audit internal bertanggung jawab kepada seseorang dalam perusahaan yang memiliki kewenangan yang memadai untuk memastikan cakupan audit yang luas serta pertimbangan yang cukup, efektifnya tindakan dan juga rekomendasi audit. 
2. Memiliki komunikasi langsung dengan komisaris ataupun komite audit.

Sihombing dan Indarto(2014) menyatakan faktor-faktor yang mempengaruhi Independensi internal auditor :

1. Konflik peran

2. Ambiguitas peran

3. Status organisasi

4. Dukungan manajemen

5. Praktek penggunaan fungsi internal audit sebagai batu loncatan bagi karir masa depan

\section{Profesionalisme}

Profesionalisme dapat diartikan sebagai kemampuan yang dimiliki oleh seseorang dalam melaksanakan pekerjaannya sesuai dengan standar pekerjaan yang berlaku (Christian, 2012). Profesionalisme Auditor Internal merupakan sikap dan juga perilaku dari auditor itu sendiri dalam melaksanakan profesinya dengan kesungguhan dan juga tanggung jawab agar dapat mencapai kinerjanya dengan baik (Nugrahini,2015). Dalam Sihombing dan Indarto (2014) menyatakan bahwa seorang auditor internal haruslah menggunakan kompetensi yang dimiliki agar dapat bekerja secara professional.

Sawyer's (2012) dinyatakan bahwa bimbingan wajib merupakan prinsip-prinsip dan juga syarat-syarat yang mendasar untuk praktek profesional audit internal dan untuk mengevaluasi efektivitas kinerja aktivitas audit internal. Menurut Halldalam Nugrahini (2015) dinyatakan bahwa profesionalisme Auditor Internal dapat diukur dengan :

1. Pengabdian pada profesi, dicerminkan dari dedikasi profesionalisme dengan menggunakan pengetahuan serta kecakapan yang dimiliki.

2. Keteguhan dalam melaksanakan pekerjaannya meskipun imbalan kurang. Kewajiban sosial, pandangan mengenai pentingnya profesi dan juga manfaat yang diperolehnya.

3. Kemandirian, seorang yang professional mampu membuat keputusan sendiri tanpa adanya tekanan dari pihak lain.

4. Keyakinan terhadap peraturan profesi, keyakinan bahwa yang paling berwenang untuk menilai pekerjaannya telah professional atau belum adalah rekan sesame profesinya, buka orang yang tidak memiliki kompetensi dalam bidang ilmu serta pekerjaan mereka.

5. Hubungan dengan sesama profesi,menggunakan ikatan profesi sebagai acuan, baik dalam organisasi formal maupun kelompok kolega informal.

\section{Kualitas Audit}

Kemampuan professional dari seorang individu dalam melakukan pekerjaanya disebut dengan kualitas auditor. Kualitas audit merupakan pelaksanaan audit yang dilakukan sesuai dengan standar yang ada sehingga dapat mengungkapkan dan juga melaporkan bila terjadi pelanggaran yang dilakukan oleh klien. Selain itu kualitas audit dapat dikatakan berkualitas bila telah memenuhi dari segi standar auditing dan juga standar pengendalian mutu (Agusti, 2013). Menurut De Angelo (1981) dalam Alim dkk. (2007) menyatakan bahwa kualitas audit merupakan suatu probabilitas dari seorang auditor yang menemukan dan juga melaporkan ada atau tidaknya suatu pelanggaran yang terjadi didalam sistem akuntansi kliennya.Indikator yang digunakan untuk mengukur kualitas audit yaitu Kualitas proses, pengauditan yang dilakukan dengan cermat, sesuai prosedur yang ada dan terus mempertahankan sikap skeptic (Efendy,2010).

\section{Kompetensi berpengaruh positif terhadap kualitas audit}

Kompetensi adalah pengetahuan, keterampilan dan juga kemampuan yang dibutuhkan oleh seseorang dalam menjalankan pekerjaannya (Mayasari,2010). Kompetensi juga dapat 
diperoleh dari pengalaman yang selama menjalankan tugasnya.Beberapa penelitian terdahulu seperti penelitian yang dilakukan oleh Alim dkk(2007); Efendy (2010) dan Rumengan (2014), menyatakan bahwa kompetensi berpengaruh positif terhadap kualitas audit. Maka dapat dikatakan bahwa seorang auditor yang memiliki kompetensi yang tinggi akan menghasilkan kualitas audit yang lebih baik. (Rumengan,2014).

Hal tersebut disebabkan kompetensi yang tinggi akan menjadikan auditormemiliki lebih banyak engetahuan dalam bidang yang digelutinya, maka auditor tersebut akan dapat mengerti masalah-masalah yang ditemui secara lebih mendalam. Lain halnya dengan auditor yang memiliki kompetensi yang rendah. Apabila seorang auditor memiliki kompetensi yang rendah akan menghadapi kesulitan untuk menemukan temuan masalah (Nugrahini,2015). Jadi kompetensi menentukan keberhasilan seorang auditor dalam melaksanakan tugasnya. Maka dari uraian diatas dapat ditarik hipotesis sebagai berikut:

\section{H1: Kompetensi Berpengaruh Positif Terhadap Kualitas Audit}

\section{Independensi berpengaruh positif terhadap kualitas audit}

Independensi merupakan hal yang penting dalam melaksanakan audit selain kompetensi. Mulyadi(2013) dalam Priyansari(2015) menyatakan independensi merupakan keadaan yang bebas dari pengaruh, maksudnya adalah tidak dikendalikan ataupun tergantung pada pihak lain. Dalam penelitian terdahulu yang dilakukan oleh Ardini (2010); Priyansari (2015); dan Andarwanto (2015) menghasilkan bahwa independensi berpengaruh positif terhadap kualitas audit. Jadi apabila seorang auditor memiliki tingkat independensi yang tinggi maka akan menghasilkan audit yang juga berkualitas tinggi pula (Agusti, 2013).

Seorang auditor bertugas untuk mengumpulkan semua informasi yang dibutuhkan untuk melaksanakan audit dan juga untuk pengambilan keputusan audit yang dilakukannya (Rumengan,2014). Maka dari itu sikap indepeden seorang auditor sangat diperlukan karena tanpa adanya sikap independensi dari auditor maka laporan audit yang dihasilkan akan tidak sesuai dengan kenyataan yang ada (Efendy,2010). Maka auditor yang tetap mempertahankan sikap independensinya dalam kondisi apapun akan dapat menghasilkan kualitas audit yang juga akan semakin baik (Harsanti,2014). Maka dari uraian diatas dapat ditarik hipotesis sebagai berikut:

\section{H2: Independensi Berpengaruh Positif Terhadap Kualitas Audit}

\section{Profesionalisme berpengaruh positif terhadap kualitas audit.}

Selain memiliki kompetensi dan juga independensi yang tinggi seorang auditor juga diharapkan untuk memiliki profesionalisme yang baik dalam melaksanakan pekerjaannya. Profesionalisme adalah suatu sikap yang bertanggung jawab terhadap apa yang telah menjadi tugasnya. Penelitian yang dilakukan oleh Nteseo(2013); Nugrahini (2015); dan Andarwanto(2015), menyatakan bahwa profesionalisme berpengaruh positif terhadap kualitas audit. Jadi dapat disimpulkan bahwa seorang auditor yang memiliki tingkat profesionalisme yang tinggi maka akan dapat mengasilkan audit yang berkualitas tinggi pula.

Hal tersebut dikarenakan dengan sikap profesionalisme auditor yang tinggi akan dapat menunjukkan bahwa auditor tersebut telah menjalankan tugasnya dengan professional. Sehingga hal tersebut dapat memberi nilai tambah untuk meningkatkan kualitas dari audit itu sendiri (Harsanti, 2014). Seorang auditor yang menyadari akan tanggung jawabnya maka 
auditor tersebut akan berusaha lebih keras untuk menyelesaikan apa yang menjadi tanggung jawabnya. Maka dari uraian diatas dapat ditarik hipotesis sebagai berikut:

\section{H3: Profesionalisme Berpengaruh Positif Terhadap Kualitas Audit}

\section{METODA PENELITIAN}

\section{Populasi dan Sampel Penelitian}

Populasi dalam penelitian ini adalah Internal Auditor yang bekerja di Perusahaan Manufaktur yang ada di Semarang. Informasi data yang ada penulis peroleh terdapat 278 perusahaan manufaktur di Semarang, data tersebut diperoleh dari Direktori Industri Manufaktur Jawa Tengah 2014. Teknik pengambilan sampel menggunakan purposive sampling yaitu internal auditor yang bekerja di perusahaan manufaktur dan internal auditor yang bersedia untuk menjadi responden.

\section{Sumber dan Jenis Data}

Penelitian ini akan menggunakan data primer. Sumber data yang diperoleh langsung yang berasal dari sumber yang asli disebut dengan data primer (Andriandi, 2010). Dalam penelitian ini data primer yang digunakan berupa kuesioner atau tanggapan langsung dari responden mengenai Kompetensi, Independensi, Profesionalisme dan juga Kualitas Audit. Responden dalam penelitian ini adalah Internal Auditor yang bekerja di perusahaan manufaktur di Semarang.

\section{Definisi dan Pengukuran Variabel Penelitian}

Dalam penelitian ini terdapat satu variabel dependen yaitu kualitas audit, dan juga tiga variabel independen yaitu kompetensi,independensi dan profesionalisme. Secara operasional berikut adalah uraian dari variabel-variabel dalam penelitian :

\section{Kompetensi (X1)}

Kompetensi adalah pengetahuan, keahlian yang dimiliki oleh seorang auditor internal yang diperoleh melalui pendidikan dan juga pelatihan professional. Dalam penelitian ini tingkat kompetensi auditor dinilai berdasarkan 10 pernyataan. Pernyataan tersebut mengenai pengetahuan, keterampilan, serta sikap perilaku yang dimiliki dan juga pendidikan dan pelatihan professional berkelanjutan yang telah ditempuh. Skala yang digunakan dalam penelitian ini menggunakan skala Likert dengan nilai 1 Sangat Tidak Setuju (STS) yang menunjukkan bahwa auditor tidak kompeten hingga nilai 5 Sangat Setuju (SS) yang menunjukkan bahwa auditor semakin kompeten.

\section{Independensi (X2)}

Independensi adalah sikap yang tidak memihak dan juga tidak mudah untuk dipengaruhi pihak lain dalam melaksanakan pemeriksaan untuk peyusunan laporan audit. Penelitian ini menggunakan 9 pernyataan untuk mengukur tingkat independensi auditor. Pernyataan tersebut terkait dengan pelaksanaan audit yang bebas dari campur tangan pihakpihak tertentu, bebas dari kepentingan pribadi dan juga pelaporan audit telah sesuai dengan fakta yang ada. Skala yang digunakan adalah skala Likert dengan nilai 1 Sangat Tidak Setuju (STS) yang menunjukkan bahwa auditor tidak independensi hingga nilai 5 Sangat Setuju (SS) yang menunjukkan bahwa auditor semakin independensi. Terkecuali untuk pernyataan no 5, nilai 1 Sangat Tidak Setuju (STS) akan menunjukkan bahwa auditor bersikap independensi hingga nilai 5 Sangat Setuju (SS) yang menunjukkan bahwa auditor bersikap tidak independensi. 


\section{Profesionalisme (X3)}

Profesionalisme merupakan seseorang yang menggunakan seluruh kemampuan, pengetahuan sertaa pengalamannya dalam menjalankan pekerjaannya. Dalam penelitian ini terdapat 10 pernyataan untuk mengukur profesionalisme auditor. Pernyataan-pernyataan tersebut terkait dengan pengabdian pada profesi, kewajiban sosial, kemandirian, keyakinan terhadap peraturan profesi dan juga hubungannya denag rekan seprofesi. Skala yang digunakan dalam penelitian ini menggunakan skala Likert dengan nilai 1 Sangat Tidak Setuju (STS) yang menunjukkan bahwa auditor bersikap tidak profesionalisme hingga nilai 5 Sangat Setuju (SS) yang menunjukkan bahwa auditor bersikap profesionalisme.

\section{Kualitas Audit (Y)}

Kualitas audit merupakan hasil audit yang telah memenuhi standar yang ada, sehingga dapat menghasilkan laporan audit yang akurat, lengkap dan juga objektif. Dalam penelitian ini terdapat 10 pernyataan untuk mengukur kualitas audit. Pernyataan tersebut terkait dengan proses audit, proses pengumpulan bukti, membuat kesimpulan dan juga laporan audit yang dihasilkan. Skala yang digunakan dalam penelitian ini menggunakan skala Likert dengan nilai 1 Sangat Tidak Setuju (STS) yang menunjukkan bahwa kualitas audit tidak baik hingga nilai 5 Sangat Setuju (SS) yang menunjukkan bahwa kualitas audit baik.

\section{Model Penelitian}

Pengujian hipotesis menggunakan persamaan regresi berikut ini:

$$
Y=\alpha+\beta 1 X 1+\beta 2 X 2+\beta 3 X 3+e
$$

Dimana:

$\begin{array}{ll}\mathrm{Y} & : \text { Kualitas Audit } \\ \alpha & : \text { Konstanta } \\ \beta 1, \beta 2 & \text { : Koefisien Regresi } \\ \mathrm{X} 1 & : \text { Kompetensi } \\ \mathrm{X} 2 & : \text { Independensi } \\ \mathrm{X} 3 & : \text { Profesionalisme } \\ \mathrm{e} & : \text { Eror }\end{array}$

\section{HASIL DAN PEMBAHASAN}

Sampel dalam penelitian ini adalah auditor internal yang bekerja diperusahaan manufaktur Semarang. Berdasarkan penyebaran 60 kuesioner terdapat 50 kuesioner yang kembali dan hanya 47 kuesioner yang dapat diolah. Hal tersebut dikarenakan 2 kuesioner bukan diisi oleh auditor internal dan 1 kuesioner tidak diisi secara lengkap. Pada lampiran disajikan distribusi responden berdasarkan jenis kelamin, usia, pendidikan dan juga lama bekerja.

Mayoritas responden berjenis kelamin perempuan sebanyak 25 orang $(53,2 \%)$ sedangkan sisanya pria 22 orang $(46,8 \%)$. Sedangkan usia responden dalam penelitian ini yang berusia 26 tahun sebanyak 8 orang $(17 \%)$, berusia 31 tahun sebanyak 9 orang $(19 \%)$ berusia 35 tahun sebanyak 6 orang $(12,8 \%)$ berusia 37 tahun sebanyak 7 orang $(14,9 \%)$ berusia 45 tahun sebanyak 9 orang (17\%) dan berusia 50 tahun sebanyak 8 orang (17\%). Sehingga dapat disimpulkan mayoritas responden berusia 31 tahun dan juga 45 tahun. Dari segi pendidikan terakhir sebanyak 4 orang $(8,5 \%)$ memiliki tingkat pendidikan D3, pendidikan S1 sebanyak 23 orang (48,9\%), pendidikan S2 sebanyak 13 orang $(27,7 \%)$ dan pendidikan sebanyak 7 orang $(14,9 \%)$. Maka mayoritas responden memiliki pendidikan 
terakhirnya adalah S1,dan berdasarkan lama bekerja orang yang bekerja antara 1-3 tahun sebanyak 9 orang $(19,1 \%), 3-6$ tahun sebanyak 22 orang(46,8\%) dan lebih dari 6 tahun sebanyak16 orang (34\%) maka mayoritas responden telah bekerja antara 3-6 tahun.

\section{Uji Validitas dan Reliabilitas}

Tabel 1 hingga tabel 4 menampilkan hasil pengujian validitas dan reliabilitas masingmasing variabel penelitian.

\section{Tabel 1 \\ Validitas dan Reliabilitas Variabel \\ Kompetensi}

\begin{tabular}{|c|c|c|c|}
\hline Variabel & $\begin{array}{c}\text { Cronbach's } \\
\text { Alpha }\end{array}$ & $\begin{array}{c}\text { Cronbach's } \\
\text { Alpha if Item } \\
\text { Deleted }\end{array}$ & Keterangan \\
\hline KO1 & 0,841 & 0,824 & VALID \\
\hline KO2 & 0,841 & 0,837 & VALID \\
\hline KO3 & 0,841 & 0,817 & VALID \\
\hline KO4 & 0,841 & 0,804 & VALID \\
\hline KO5 & 0,841 & 0,833 & VALID \\
\hline KO6 & 0,841 & 0,833 & VALID \\
\hline KO7 & 0,841 & 0,826 & VALID \\
\hline KO8 & 0,841 & 0,829 & VALID \\
\hline KO9 & 0,841 & 0,827 & VALID \\
\hline KO10 & 0,841 & 0,833 & VALID \\
\hline
\end{tabular}

Dari tabel 1 dapat dilihat bahwa variabel kompetensi memiliki nilai Cronbach's Alpha sebesar 0,841 yang berarti reliabiltas yang tinggi. Dari 10 pernyataan yang ada mengenai kompetensi 10 pernyataan tersebut memiliki nilai yang valid. Hal tersebut dikarenakan 10 pernyataan tersebut memiliki nilai Cronbach Alpha if Item Deleted yang lebih kecil dari 0,841. Dari tabel 2 dapat dilihat bahwa variabel independensi menghasilkan Cronbach's Alpha sebesar 0,934 dan memiliki reliabilitas yang sempurna. Dari 9 pernyataan mengenai independensi, hanya 7 pernyataan yang bernilai valid. Dari tabel 3 dapat dilihat bahwa variabel profesionalisme menghasilkan Cronbach's Alpha 0,954 yang berarti memiliki reliabilitas yang sempurna. Terdapat 10 pernyataan terkait profesionalisme, dan 10 pernyataan tersebut bernilai valid. Dari tabel 4 dapat dilihat bahwa variabel kualitas audit menghasilkan nilai Cronbach's Alpha 0,937. nilai Cronbach's Alpha tersebut menunjukan bahwa alat uji variabel kualitas audit memiliki reliabilitas yang sempurna. Terdapat 10 pernyataan terkait kualitas audit, dan hanya 8 pernyataan yang bernilai valid. 
Tabel 2

Validitas dan Reliabilitas Variabel

Independensi

\begin{tabular}{|c|c|c|c|}
\hline Variabel & $\begin{array}{c}\text { Cronbach's } \\
\text { Alpha }\end{array}$ & $\begin{array}{c}\text { Cronbach's } \\
\text { Alpha if Item } \\
\text { Deleted }\end{array}$ & Keterangan \\
\hline IN1 & 0,934 & 0,925 & VALID \\
\hline IN2 & 0,934 & 0,919 & VALID \\
\hline IN3 & 0,934 & 0,914 & VALID \\
\hline IN4 & 0,934 & 0,919 & VALID \\
\hline IN6 & 0,934 & 0,934 & VALID \\
\hline IN7 & 0,934 & 0,929 & VALID \\
\hline IN8 & 0,934 & 0,925 & VALID \\
\hline
\end{tabular}

Tabel 3

Validitas dan Reliabilitas Variabel

Profesionalisme

\begin{tabular}{|c|c|c|c|}
\hline Variabel & $\begin{array}{c}\text { Cronbach's } \\
\text { Alpha }\end{array}$ & $\begin{array}{c}\text { Cronbach's Alpha } \\
\text { if Item Deleted }\end{array}$ & Keterangan \\
\hline PR1 & 0,954 & 0,950 & VALID \\
\hline PR2 & 0,954 & 0,949 & VALID \\
\hline PR3 & 0,954 & 0,946 & VALID \\
\hline PR4 & 0,954 & 0,950 & VALID \\
\hline PR5 & 0,954 & 0,948 & VALID \\
\hline PR6 & 0,954 & 0,946 & VALID \\
\hline PR7 & 0,954 & 0,948 & VALID \\
\hline PR8 & 0,954 & 0,948 & VALID \\
\hline PR9 & 0,954 & 0,951 & VALID \\
\hline PR10 & 0,954 & 0,951 & VALID \\
\hline
\end{tabular}


Tabel 4

Validitas dan Reliabilitas Variabel

Kualitas Audit

\begin{tabular}{|c|c|c|c|}
\hline Variabel & $\begin{array}{c}\text { Cronbach's } \\
\text { Alpha }\end{array}$ & $\begin{array}{c}\text { Cronbach's Alpha if Item } \\
\text { Deleted }\end{array}$ & Keterangan \\
\hline KA1 & 0,937 & 0,936 & VALID \\
\hline KA2 & 0,937 & 0,924 & VALID \\
\hline KA3 & 0,937 & 0,922 & VALID \\
\hline KA4 & 0,937 & 0,928 & VALID \\
\hline KA5 & 0,937 & 0,932 & VALID \\
\hline KA6 & 0,937 & 0,926 & VALID \\
\hline KA7 & 0,937 & 0,930 & VALID \\
\hline KA8 & 0,937 & 0,927 & VALID \\
\hline
\end{tabular}

\section{Statistik Deskriptif}

Tabel 5 menyajikan statistik deskriptif pola distribusi masing-masing variabel. Berdasarkan tabel diatas dapat diketahui bahwa kualitas audit dari responden memiliki nilai minimum 1,90 dan nilai maksimum 5,00. Sedangkan untuk rata-rata tingkat kualitas audit adalah sebesar 3,14 (termasuk dalam skala yang sedang). Artinya kualitas audit yang dihasilkan oleh auditor diperusahaan manufaktur Semarang sedang. Lalu untuk variabel kompetensi memiliki nilai minimum sebesar 2,8 dan nilai maksimum sebesar 5,00 dari sepuluh pernyataan kuesioner. Sedangkan untuk nilai rata-ratanya adalah 3,948 (termasuk rentang skala tinggi). Hal tersebut menunjukkan bahwa rata-rata menilai responden bahwa kompetensi yang dikuasai oleh auditor internal termasuk cukup.

Lalu pada variabel independensi memiliki nilai minimum 2,9 dan maksimum 5,00 dari sembilan pertanyaan kuesioner. Rata-rata perolehan nilai pada variabel ini adalah sebesar 3,861 (termasuk rentang skala yang tinggi). Hal tersebut menunjukkan bahwa responden rata-rata menilai bahwa independensi yang dikuasainya cukup. Dan juga pada variabel profesionalisme memiliki nilai minimum 1,9 dan maksimum 5,00 dari sepuluh pertanyaan kuesioner. Rata-rata perolehan nilai pada variabel ini adalah sebesar 3,444 (termasuk rentang skala sedang). Hal tersebut menunjukkan bahwa responden rata-rata menilai bahwa profesionalisme yang telah dimilikinya cukup baik. 
Tabel 5

Statistik Deskriptif

\begin{tabular}{|c|c|c|c|c|c|c|c|}
\hline \multirow{2}{*}{ Variabel } & \multirow{2}{*}{ Min } & \multirow{2}{*}{$\operatorname{Max}$} & \multirow{2}{*}{ Mean } & \multicolumn{3}{|c|}{ Rentang Skala } & \multirow[b]{2}{*}{ Keterangan } \\
\hline & & & & Rendah & Sedang & Tinggi & \\
\hline Kualitas Audit & 1,90 & 5,00 & 3,14 & $1-2,33$ & $2,34-3,67$ & $3,68-5$ & Sedang \\
\hline Kompetensi & 2,8 & 5,00 & 3,948 & $1-2,33$ & $2,34-3,67$ & $3,68-5$ & Tinggi \\
\hline Independensi & 2,9 & 5,00 & 3,861 & $1-2,33$ & $2,34-3,67$ & $3,68-5$ & Tinggi \\
\hline Profesionalisme & 1,9 & 5,00 & 3,444 & $1-2,33$ & $2,34-3,67$ & $3,68-5$ & Sedang \\
\hline
\end{tabular}

\section{HASIL PENGUJIAN HIPOTESIS}

Hasil pengujian hipotesis dapat dilhat pada tabel 6. Dari kolom t tersebut dapat diketahui variabel independen berpengaruh terhadap variabel dependen jika nilainya $\mathrm{T}$ hitung lebih besar dari $\mathrm{T}$ tabel,yaitu sebesar 1,681. Pada variabel diatas menunjukkan bahwa kompetensi, independensi dan juga profesionalisme berpengaruh terhadap kualitas audit, hal tersebut ditunjukkan dengan nilai T hitung yang dihasilkan lebih besar dari 1,681.

Tabel 6

\section{Hasil Pengujian Hipotesis}

\begin{tabular}{|c|c|c|c|c|}
\hline \multirow{2}{*}{ Model } & \multicolumn{2}{|c|}{ Unstandardized Coeficients } & \multirow{2}{*}{$\begin{array}{c}\text { Standardized } \\
\text { Coefficients }\end{array}$} & t \\
\cline { 2 - 3 } & B & Std. Error & &,- 995 \\
\hline (Constant $)$ & $-1,349$ & 1,355 & & 1,725 \\
\hline KO &, 481 &, 279 &, 242 & 1,812 \\
\hline IN &, 432 &, 239 &, 252 & 2,127 \\
\hline PR &, 268 &, 126 &, 288 & \\
\hline
\end{tabular}

\section{PEMBAHASAN}

\section{Hipotesis Pertama}

Pada table 4.6, terlihat nilai t-hitung variable Kompetensiadalah 1,725> 1,681. Sehingga dapat diketahui bahwa kompetensi berpengaruh positif terhadap kualitas audit. Maka dari itu, hipotesis pertama penelitian ini diterima Karena terdukung secara empiris di Semarang. Penerimaan hipotesis ini menandakan bahwa semakin tinggi kompetensi yang dimiliki oleh auditor internal maka akan semakin baik pula kualitas audit yang akan dihasilkan. 
Selain itu semakin tinggi kompetensi yang dimiliki oleh auditor internal maka auditor tersebut akan dapat lebih mudah untuk mendalami masalah audit yang ada. Hal tersebut dikarenakan apabila auditor internal tersebut memiliki pengetahuan auditing yang luas mengenai auditing dan juga memiliki keahlian bidang metodologi audit,maka auditor internal tersebut akan dapat lebih cermat dan mudah untuk menghasilkan kualitas audit yang lebih baik. Auditor internal dapat meningkatkan pengetahuan dan keahlian di bidang metodologi audit dengan mengikuti pelatihan auditing profesi berkelanjutan, sehingga dapat memahami teknik auditing lebih baik. Kualitas audit yang dihasilkan lebih baik. Hasil penelitian ini konsisten dengan penelitian yang sebelumnya dilakukan, yaitu penelitian Alim et al. (2007); Agusti dan Pertiwi (2013) dan Nugrahini (2015) yang menyatakan bahwa kompetensi berpengaruh positif terhadap kualitas audit.

\section{Hipotesis Kedua}

Dari table 4.6, terlihat nilai t-hitung variable Independensi adalah 1,812 > 1,681. Sehingga dapat diketahui bahwa independensi berpengaruh positif terhadap kualitas audit. Maka dari itu hipotesis kedua dari penelitian ini diterima karena telah terdukung secara empiris di Semarang. Penerimaan hipotesis kedua ini menandakan bahwa semakin tinggi independensi yang dimiliki oleh auditor internal maka semakin baik kualitas audit yang dihasilkan. Auditor dapat meningkatkan independensi yang dimiliki dengan melakukan pemeriksaan dan penyusunan program audit yang bebas dari kepentingan pribadi dan juga kepentingan pihak lain.

Hal tersebut dikarenakan apabila seorang auditor internal tidak dipengaruhi oleh pihak lain maupun kepentingan pribadi maka auditor akan menyatakan pendapatnya berdasarkan pertimbangan fakta-fakta yang ada. Itu berarti semakintinggi independensi yang dimiliki oleh auditor internal semakin baik pula kualitas audit yang dihasilkannya. Hasil penelitian ini sejalan dengan penelitian yang sebelumnya dilakukan yaitu penelitian Ardini (2010); Agusti dan Pertiwi (2013) dan Priyansari (2015) yang menyatakan bahwa independensi berpengaruh positif terhadap kualitas audit.

\section{Hipotesis Ketiga}

Dari table 4.6, terlihat nilai t-hitung variable Profesionalisme adalah2,127>1,681. Sehingga dapat diketahui bahwa profesionalisme berpengaruh positif terhadap kualitas audit. Maka dari itu hipotesis ketiga dari penelitian ini diterima Karena telah terdukung secara empiris di Semarang. Dengan diterimanya hipotesis ketiga dalam penelitian ini, menandakan bahwa semakin tinggi profesionalisme yang dimiliki oleh auditor internal maka semakin baik pula kualitas audit yang dihasilkannya.

Hal tersebut dikarenakan dengan sikap profesionalisme auditor internal yang tinggi maka akan dapat menunjukkan bahwa auditor internal tersebut telah menjalankan tugasnya secara professional. Apabila seorang auditor tersebut menyadari akan tanggung jawabnya maka auditor tersebut akan berusaha lebih keras untuk menyelesaikan apa yang menjadi tanggung jawabnya. Maka auditor internal tersebut akan menggunakan segenap pengetahuan, kemampuan, dan pengalamannya dalam melaksanakan audit maka kualitas audit yang dihasilkan juga akan lebih baik. Auditor internal dapat meningkatkan profesionalisme yang dimiliki dengan menciptakan transparansi dalam masyarakat dengan menyampaikan hasil audit berdasarkan fakta yang ditemui dalam proses audit. Penelitian ini konsisten dengan penelitian Nteseo (2013), Agusti dan Pertiwi (2013), dan juga Nugrahini (2015) yang menemukan bahwa profesionalisme berpengaruh positif terhadap kualitas audit. 


\section{SIMPULAN}

Penelitian ini dilakukan untuk melihat faktor-faktor apa saja yang dapat mempengaruhi kualitas audit yang dilakukan oleh auditor internal. Faktor-faktor yang diduga mempengaruhi kualitas audit itu sendiri antara lain banyaknya kompetensi, independensi dan juga profesionalisme yang memiliki pengaruh positif. Maka setelah dilakukan riset terhadap sampel auditor internal yang bekerja di perusahaan manufaktur yang berada di Jawa Tengah didapatkan hasil antara lain:

a. Kompetensi auditor internal berpengaruh positif terhadap kualitas audit.

b. Independensi auditor internal berpengaruh positif terhadap kualitas audit.

c. Profesionalisme auditor internal berpengaruh positif terhadap kualitas audit.

Berdasarkan hasil penelitian, maka saran yang diajukan adalah sebagai berikut:

1. Auditor internal dapat meningkatkan pengetahuan dan keahlian di bidang metodologi audit dengan mengikuti pelatihan auditing profesi berkelanjutan, sehingga dapat memahami teknik auditing lebih baik.

2. Auditor internal dapat meningkatkan independensi yang dimiliki dengan melakukan pemeriksaan dan penyusunan program audit yang bebas dari kepentingan pribadi dan juga kepentingan pihak lain.

3. Auditor internal dapat meningkatkan profesionalisme yang dimiliki dengan menciptakan transparansi dalam masyarakat dengan menyampaikan hasil audit berdasarkan fakta yang ditemui dalam proses audit.

Keterbatasan penelitian ini terletak pada sampel penelitian yang diambil. Sampel penelitian ini hanya mengambil pada 14 perusahaan manufaktur dari 278 perusahaan manufaktur yang ada. Sehingga akan lebih baik bagi penelitian selanjutnya untuk dapat menambah jumlah sampel perusahaan manufaktur lainnya.

Dari kesimpulan diatas maka implikasinya adalah auditor internal haruslah memiliki kompetensi,independensi, dan juga profesionalisme yang baik. Hal tersebut dikarenakan ketiga hal tersebut berkaitan langsung dengan kualitas audit yang dihasilkannya. Maka auditor internal dapat terus melakukan proses belajarnya agar dapat meningkatkan kompetensi yang dimilikinya. Selain itu auditor internal haruslah tetap independen dan professional dalam melaksanakan perkerjaanya, sehingga kualitas audit yang dihasilkan akan lebih baik.

\section{DAFTAR PUSTAKA}

Andarwanto, A. 2015. Pengaruh Kompetensi, Independensi, Akuntabilitas dan Profesionalisme Auditor terhadap Kualitas Audit. Skripsi diterbitkan. Universitas Muhammadiyah Surakarta.

Agusti, R., dan Pertiwi, N.P. 2013. Pengaruh Kompetensi, Independensi, dan Profesionalisme terhadap Kualitas Audit. JURNAL EKONOMIVolume 21, Nomor 3 September 2013.

Alim, M.N ., Hapsari, T .,dan Liliek, P. 2007. Pengaruh Kompetensi dan Independensi Terhadap Kualitas Audit dengan Etika Auditor Sebagai Variabel Moderasi. Jurnal Simposium Nasional Akuntansi X, Universitas Brawijaya, Malang. 
Ardini, L. 2010. Pengaruh Kompetensi, Independensi, Akuntabilitas dan Motivasi terhadap Kualitas Audit. Majalah Ekonomi Tahun XX, No.3 Desember 2010. STIESIA Surabaya.

Andriandi, A. 2010. Pengaruh Profesionalisme Auditor dan Etika Profesi TerhadapPertimbangan Tingkat Materialitas Dalam Proses Pengauditan Laporan Keuangan. Skripsi diterbitkan. Universitas Islam Negeri Syarif Hidayatullah Jakarta.

Christian,Y. 2012. Peran Profesionalisme Auditor Dalam Mengukur Tingkat Materialitas Pada Pemeriksaan Laporan Keuangan. JURNAL ILMIAH MAHASISWA AKUNTANSI VOL. 1, NO. 3, MEI 2012.

Efendy, M.T. 2010. Pengaruh Kompetensi, Independensi, dan Motivasi Terhadap Kualitas Audit Aparat Inspektorat Dalam Pengawasan Keuangan Daerah. Tesis diterbitkan. Universitas Diponegoro. Semarang.

Harsanti, P dan Whetyningstyas, A. (2014). Pengaruh Kompetensi, Independensi, dan Profesionalisme Auditor Terhadap Kualitas Audit.JURNAL ILMIAH MAHASISWA AKUNTANSI - Volume 7, Nomor 1, Juni 2014.

Mayasari, D. 2011. Pengaruh Profesionalisme,Independensi,Kompetensi,Etika Profesi,dan Pengetahuan Auditor dalam Mendeteksi Kekeliruan Terhadap Ketetapan Pemberian Opini Audit oleh Auditor. Skripsi diterbitkan. Universitas Islam Negeri Syarif Hidayatullah Jakarta.

Nteseo, A. 2013. Pengaruh Profesionalisme Terhadap Kualitas Audit (Studi Pada Auditor di Provinsi Gorontalo).Skripsi diterbitkan. Universitas Muhammadiyah Surakarta.

Nugrahini, P. 2015. Pengaruh Kompetensi dan Profesionalisme Auditor Internal Terhadap Kualitas Audit. Skripsi diterbitkan. Universitas Negeri Yogyakarta.

Priyansari, A., dan Tah, N. 2015. Pengaruh Kompetensi,Independensi, dan Etika Auditor Terhadap Kualitas Audit. Skripsi diterbitkan. Universitas Dian Nuswantoro. Semarang.

Rumengan, I.P.E., dan Rahayu, S. 2014. Pengaruh Kompetensi,Independensi,dan Pengalaman Kerja Terhadap Kualitas Audit. Skripsi diterbitkan. Universitas Telkom.

Sawyer's Lawrence B. Dittenhofer. 2012. Guide For Internal Auditors.Volume 1: Internal Audit Essentials. Edisi 6. The Institute of Internal Auditors Research Foundation.

Sihombing, R.P., dan Indarto,S. L. 2014. Sistem Pengendalian Internal. Yogyakarta,Indonesia: Amara Books.

Suharti. 2013. Faktor-Faktor Yang Mempengaruhi Independensi Akuntan Publik. Skripsi diterbitkan. Universitas Dian Nuswantoro Semarang.

Yenny.,dan Zulfitry. R. 2012.Pengaruh Pengalaman Kerja,Independensi, Objektivitas, Integritas dan Kompetensi Auditor terhadap Kualitas Audit yang dihasilkan Auditor Kantor Akuntan Publik (KAP) Big Four. Thesis diterbitkan. Universitas Bina Nusantara. 